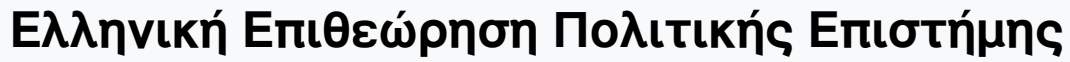

Tó 40 (2013)

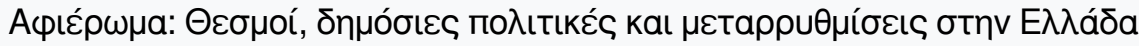

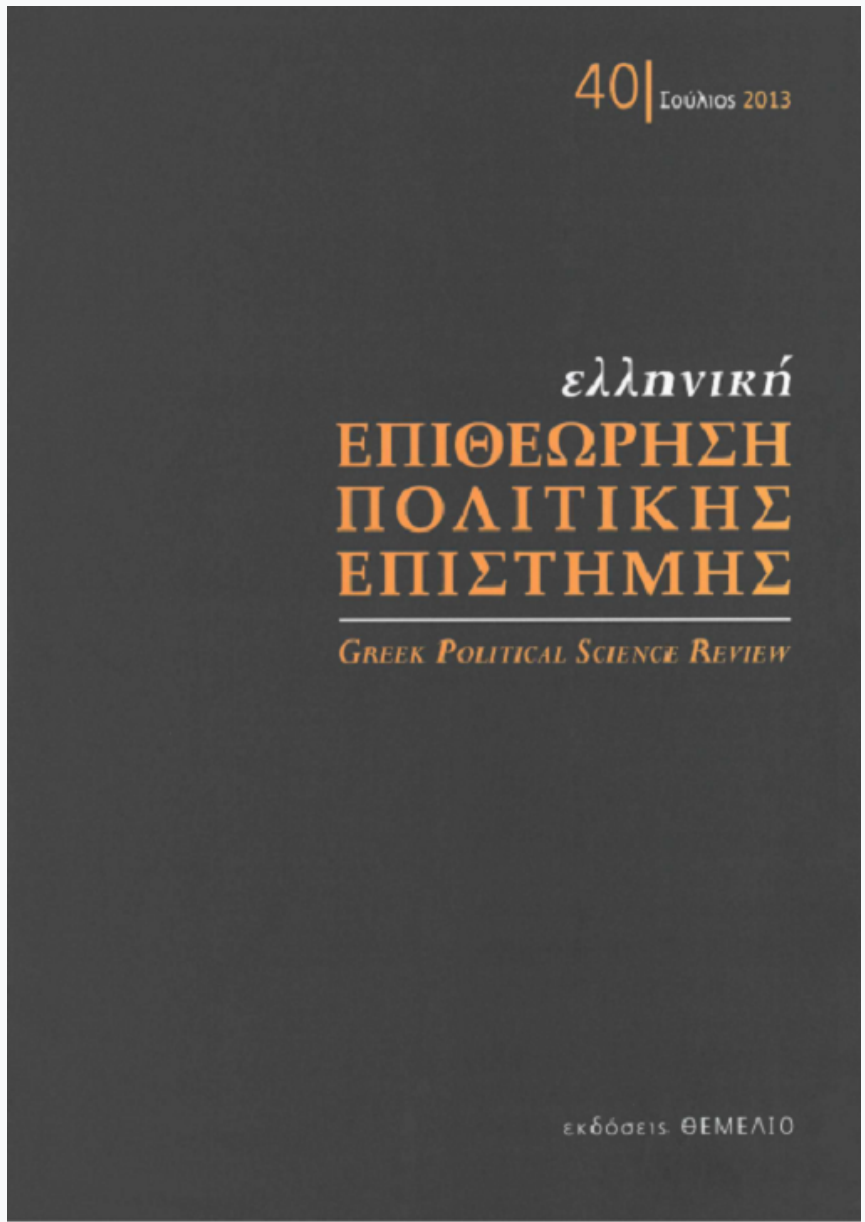

Thirty Years of Territorial Restructuring in Greece (1981-2010)

Vasilis Leontitsis

doi: $10.12681 /$ hpsa.14560

Copyright $($ 2017, Vasilis Leontitsis

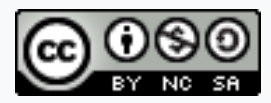

Ađ¿ıı Xpńбnৎ Creative Commons Attribution-NonCommercial-ShareAlike 4.0.

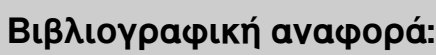

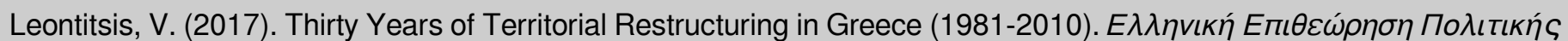
Eпıбт́́ 


\section{THIRTY YEARS OF TERRITORIAL RESTRUCTURING IN GREECE (1981-2010)}

\section{Vasilis Leontitsis*}

This article examines the decentralisation process that took place in Greece from 1981 until 2010. Although Greece remains a highly centralised state, considerable decentralisation reforms were undertaken during this period. Those reforms affected all subnational levels of government. Nevertheless, despite the considerable changes, the fundamentals of the polity have remained relatively untouched. The paper examines the causal factors of decentralisation reforms throughout this period alongside the obstructing factors that resisted them, thus contributing towards the relative inertia of the polity structures. The main argument put forward is that it was mainly domestic factors that shaped the decentralisation process in the country. Party politics, the democratisation discourse and, later on, managerial concerns influenced the reform process greatly. Additionally, structural characteristics of the Greek socio-political system, such as veto points at the local and national levels, obtruded change, while the role of certain individual actors who acted as policy entrepreneurs and pushed the reforms up the political agenda should not be underestimated. Europeanisation and other international factors were of secondary importance in the whole process. Nevertheless, one should not overlook them altogether, since their interrelation with the aforementioned domestic factors produced considerable consequences.

\section{INTRODUCTION}

The Greek polity is one of the most centralised in Europe. Historical conditions have contributed towards creating and sustaining a centralistic and rather anachronistic polity design. However, a number of decentralisation reforms have indeed taken place within the last thirty years. In that sense, it is imperative to assess the reforms that have occurred and their importance.

Contrary to the Greek legal and political tradition, the wider English-

* Dr Vasilis Leontitsis is Politics Tutor at Sheffield International College. 
speaking literature defines decentralisation as the overarching process of transferring powers to subnational authorities. Hence, it refers to the "process of state reform composed by a set of public policies that transfer responsibilities, resources, or authority from higher to lower levels of government in the context of a specific type of "state". ${ }^{1}$ Decentralisation, thus, is the transfer of political, administrative and/or financial power from the centre to any subnational authority, whereas deconcentration is the transfer of administrative and/or fiscal (but not political) power only to those authorities that are directly accountable to the central state. Hence, deconcentration is just an aspect or a sub-category of decentralisation. This is how the two terms will be used here.

The present article explores the territorial restructuring reforms that have taken place since 1981. The main argument put forward is that Greece has indeed managed to decentralise its polity within the period covered by this analysis. Regional authorities have been created and regional government elections have finally taken place; the municipalities have been strengthened and increased in size; and a more lasting subnational government design has been put in place. However, there are certain elements that have remained intact, and the polity at large remains centralistic. The European Union has not proven to be the most decisive factor in altering the system. Instead, it is domestic factors that have been of the greatest importance for both inertia and change. However, the interplay between domestic and international factors has been responsible for some of the changes that have taken place, which is something that should not be overlooked.

Before embarking on any analysis, the author would like to clarify that the aim of this article is not to separate clearly between the different factor, nor to expose any universal or widely applicable laws underpinning territorial restructuring. This is not possible in open systems, such as the ones we analyse in social sciences in general and in political science in particular, but only in closed systems. ${ }^{2}$ The latter allow for experimental activity that can potentially measure the exact effects of each factor by keeping other factors, constant, while the former do not. This is a principal position of critical realism, the ontological and epistemological position that underpins this research.

Additionally, one needs to bear in mind that in our societies most phe-

1. T.G. Falleti, "A Sequential Theory of Decentralization: Latin American Cases in Comparative Perspective", American Political Science Review, V. 99 (3), 2005, p. 328.

2. For the concepts of open and closed systems, see R. Bhaskar, A Realist Theory of Science, Leeds Books Ltd., Leeds 1975. 
nomena are multi-causal. Hence, events can only be seen as conjunctures, that is, as resulting from a number of factors. ${ }^{3}$ Multi-causality can potentially reveal another issue that might arise when one attempts to clearly separate between different factors. For such an act would leave out the combined effects causal factors have, which might prove to be crucial for the final outcome.

To sum up, the aim of this piece is predominantly to identify the different factors and try to see how they interrelate to produce results. In a number of cases, effort will be made to determine whether some factors have been more pronounced than others in shaping an outcome, but one always needs to bear in mind that factors have worked together and never in complete isolation. In practice, clear and quantifiable separation is impossible and indeed even unnecessary, since events manifest themselves as products of causal mechanisms, which comprise a number of causal factors and the way in which they interrelate.

The subject of the political decentralisation in Greece has been dealt with before. ${ }^{4}$ Nevertheless, since the process is ongoing, research that has taken place in previous years has missed out on recent reforms. Another flaw in the existing literature, and the English-speaking literature in particular, literature is that it tends to be preoccupied a priori with the EU as the overarching factor of change. This way of dealing with the subject is methodologically flawed. Starting from the causes in order to examine the effect can lead us to attribute

3. Ibid.

4. Indicatively, see F. Papageorgiou - S. Verney, "Regional Planning and the Integrated Mediterranean Programmes in Greece", in R. Leonardi (ed.), The Regions and the European Community, Frank Cass, London 1993, pp. 139-161; K. Featherstone - G.N. Yannopoulos, "The European Community and Greece: Integration and the Challenge to Centralism", in M. Keating - B. Jones (eds.), The EU and the Regions, Clarendon Press, Oxford 1995, pp. 249266; P.C. Ioakimidis, "EU Cohesion Policy in Greece: The Tension Between Bureaucratic Centralism and Regionalism", in L. Hooghe (ed.), Cohesion Policy and European Integration, Oxford University Press, Oxford 1996, pp. 342-363; P.C. Ioakimidis, "The Europeanization of Greece: An Overall Assessment", in K. Featherstone - G. Kazamias (eds.), Europeanization and Southern Periphery, Frank Cass, London and Portland, Or. 2001, pp.73-94; N.K. X $\lambda \dot{\varepsilon}-$

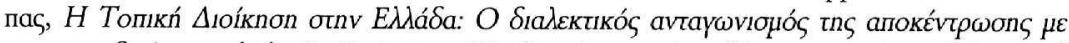
tnv autooıoíknon, ibid.; P. Getimis - C.J. Paraskevopoulos, "Europeanization of Regional Policy and Institution-Building in Greece: A Neglected Aspect of Policy Evaluation?" Paper presented at the Regional Studies Association Conference on "Evaluation and EU Regional Policy: New Questions and Challenges", Aix En Provence 31 May-1 June 2002; G. Andreou, "EU Cohesion Policy in Greece: Patterns of Governance and Europeanization", South European Society \& Politics, Vol. 11 (2), 2006, pp. 241-259. 
the effect solely to the cause(s) we have originally had in mind. In other words, problems of mono-causality may occur. Although the EU may be important, one should try to co-examine the possible influence of other factors, such as domestic ones. Europeanization and globalisation have been analysed excessively during the last years. However, as Bukowski et al. have noted, there is a danger of over-relying on macrodeterminism from above. ${ }^{5}$

This article follows the theoretical layout proposed in the introduction of this special issue. Hence, the theoretical foundations are based on historical institutionalism. The latter allows us to observe dynamic phenomena, while restoring the importance of historical conditions in defining current political arrangements. Historical institutionalism, as a structural theory, does not accommodate well for the actions of certain actors in changing political systems. ${ }^{6}$ However, certain actions taken by key actors have proven to change historical conditions and led to lasting change. Hence, the analysis to follow will keep an open eye regarding the actors' ability to bring about transformation.

Finally, the article covers the period from 1981 until the latest local government reform; the so-called "Kallikratis" reform. The year 1981 has not been chosen randomly. 1981 is the year when the Greek Socialist Party (PASOK) gained power in Greece for the first time, promising the radical decentralisation of the polity. In the same year, Greece became officially a member of the EEC. Thus, if one is to explore to what extent the EU has been a main factor towards reforming the system, 1981 is the logical year to start from.

\section{THEORY}

The introduction of this special issue has already discussed some of the major issues surrounding historical institutionalism. Hence, this section will only give a schematic account of this theoretical perspective, its main proposals and debates surrounding it.

5. J. Bukowski et al., "Introduction", in J. Bukowski et al. (eds.), Between Europeanization and Local Societies: The Space of Territorial Governance, Rowman \& Littlefield Publishers, Lanham, Md. and Oxford 2003, pp. 1-21.

6. See the Introduction of this special issue; see also the interesting debate that took place between C. Hay - D. Wincott, "Structure, Agency and Historical Institutionalism", Political Studies, Vol. XLVI, 1998, pp. 951-957 and P.A. Hall - R.C.R. Taylor, "The Potential of Historical Institutionalism: A Response to Hay and Wincott", Political Studies, Vol. XLVI, pp. 958-962. 
Historical institutionalism (HI) is one of the major strands of new institutionalism, the others being rational choice, sociological institutionalism and discursive institutionalism. ${ }^{7}$ It puts emphasis on time, timing and tempo, and is well suited to analyse dynamic phenomena that span through long periods of time. As a theoretical perspective, HI can be used as an umbrella theory, incorporating elements from all other strands of new institutionalism. ${ }^{8}$ In that sense, it could explore not only material phenomena, but ideational ones as well, combining the tangible explanations of rational choice with the more nuanced and abstract explanations of sociological and discursive institutionalisms.

$\mathrm{HI}$, like all strands of new institutionalism, is interested in institutions in the broader sense, since it is claimed that the socio-political world around us is kept together by these institutions. Hence, it is fundamental for HI to explore how they reproduce themselves and how they change. The themes of continuity and change are so important that they have become its critical point of focus.

According to $\mathrm{HI}$, continuity is achieved by what is called path dependence. Path dependence in simple terms means that, since an institution has been created and a path of action has been adopted, change is hard to occur. The more time has passed since the creation of the institution, the more difficult it is to change or abolish it. Institutions become "sticky" and institutional inertia is the outcome. ${ }^{9}$

According to Pierson ${ }^{10}$ and Mahoney, ${ }^{11}$ institutional stickiness is the outcome of self-reinforcing sequences that are connected to positive feedback. The longer an institution is around, the more desirable it is to retain it rather than start a new path. There are a number of arguments explaining why this is so. Institutional creation is a process that demands for a lot of human effort

7. P.A. Hall - R.C.R. Taylor, "Political Science and the Three New Institutionalisms", Political Studies, Vol. 44 (5), 1996, pp. 936-957; V.A. Schmidt, "Discursive Institutionalism: The Explanatory Power of Ideas and Discourse, Annual Review of Political Science, Vol. 11, 2008, pp. 303-326.

8. M.A. Pollack, "The New Institutionalisms and European Integration", in A. Wiener T. Diez (eds.), European Integration Theory, Oxford University Press, Oxford 2004, p. 139.

9. P. Pierson, "Increasing Returns, Path Dependence, and the Study of Politics", American Political Science Review, Vol. 94 (2), 2000, pp. 251-267.

10. Ibid; P. Pierson, Politics in Time: History, Institurions and Social Analysis, Princeton University Press, Princeton, N.J. and Oxford 2004.

11. J. Mahoney, "Path Dependence in Historical Sociology", Theory and Society, Vol. 29, 2000, pp.507-548. 
and entails considerable material costs. ${ }^{12}$ Additionally, the fact that there is a certain way of doing things reduces uncertainty, whereas the creation of new institutional arrangements will demand for a period of learning; it might even reduce productivity. Another explanation is that an institutional setting reflects and also reinforces certain power arrangements. ${ }^{13}$ It is obvious that the actors who have been empowered by the functioning of a certain institution will try to perpetuate its existence. Veto points are created and changing the institutional design becomes a difficult and rather cumbersome process. Finally, when an institution has been present for a long period of time, its existence inevitably becomes naturalised. ${ }^{14}$ Actors sometimes find an institution so engrained to their own lives that in some cases they might even consider its abolishment unimaginable.

Those are some reasons that explain why institutions do reproduce themselves and why inertia is so common. However, sometimes institutions do change, and the question is how. From time to time, conditions are ripe for a change of paths. This is when a critical juncture, or a window of opportunity, arises. $^{15}$ When the window of opportunity is seized, a turning point is achieved. When it is not, the window of opportunity eventually closes and change does not occur.

However, not all HI proponents adhere to this paradigm, which states that periods of continuity are followed by intervals of change; the so-called punctuated equilibrium thesis. Change is not always something that happens fast and profoundly. On the contrary, in most cases, it comes about slowly. Hence, as this line of argument goes, it is naïve to believe that we can separate between periods of changes and periods of stasis. Change happens constantly and in most cases incrementally. A number of scholars have tried to explore those processes of continuous, albeit incremental changes. ${ }^{16}$ Streeck and

12. Ibid; P. Pierson, Politics in Time: History, Institutions and Social Analysis, op.cit.

13. P. Pierson, "Not Just What, but When: Timing and Sequence in Political Processes", Studies in American Political Development, Vol. 14, 2000, p. 77; K. Thelen, "Timing and Temporality in the Analysis of Institutional Evolution and Change", Studies in American Political Development, Vol. 14, 2000, p. 103.

14. J. Mahoney, "Path Dependence in Historical Sociology", op.cit., p. 523.

15. J.W. Kingdon, Agendas, Alternatives, and Public Policies, 2nd ed., HarperCollins, New York 1995.

16. K. Thelen, "Timing and Temporality in the Analysis of Institutional Evolution and Change", op.cit.; K. Thelen, "How Institutions Evolve: Insights from Comparative Historical Analysis", in J. Mahoney - D. Rueschemeyer (eds.), Comparative Historical Analysis in the 
Thelen, in particular, have distinguished between a number of such processes; namely of displacement, layering, drift, conversion and exhaustion. ${ }^{17}$ Those different processes have something in common. They reveal instances when change is gradual, taking a long period of time to fully manifest itself. Sometimes change is so minute in a given period that it remains almost undetected, but in the long term it might have considerable repercussions. After discussing the relevant evidence in the following sections, I shall return to the theoretical issues at the end of this article.

\section{THE 1980's}

Greece is a very centralised state. A series of reforms throughout the 19th and early 20 th century decisively empowered the central state at the expense of subnational government authorities. ${ }^{18}$ Hence, at the beginning of the 1980s the Greek territorial administrative structure consisted of only one level of local self-government; the municipalities. They were small in terms of size and population, and their political weight was negligible. Regions did not exist. Instead, the only bodies of deconcentrated government were at the prefectural level. The prefect was appointed by the government and served for a set number of years. Subnational authorities were, above all, systematically starved of funding. Without the necessary funds, they could not even effectively exercise the little power they did possess.

When PASOK came to power in 1981, it had already formulated a party platform strongly in favour of decentralisation. This was the first time in modern Greece that a political party adopted a language strongly supporting the territorial restructuring of the country.

However, the radical decentralisation initially promised was not meant to

Social Sciences, Cambridge University Press, Cambridge 2003, pp. 208-240; W. Streeck - K. Thelen, "Introduction: Institutional Change in Advanced Political Economies", in W. Streeck K. Thelen (eds.), Beyond Continuity: Institutional Change in Advanced Political Economies, Oxford University Press, Oxford, pp. 1-39.

17. Ibid.

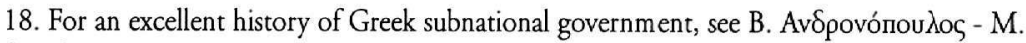

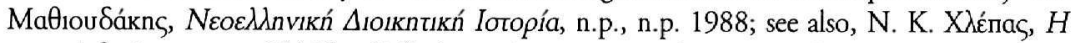

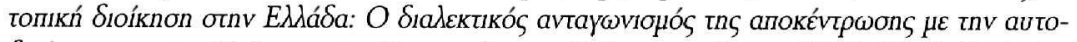
Sıoíknon, op.cit.; V. Leontitsis, Decentralisation Reforms in Greece (1981-2008): Exploring Inertia and Change, Unpublished Phd Thesis, University of Sheffield, Sheffield 2009. 
happen. Instead, a number of laws were initiated that only marginally changed the subnational government landscape. Hence, Law 1235/82 attempted to revitalise prefectural councils, which, nevertheless, were not to be elected directly. Law 1270/82 provided for the establishment of neighbourhood coun-

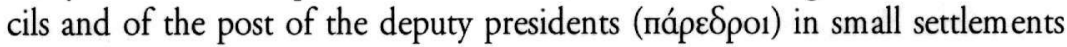
belonging to bigger municipalities. Those new innovations were not accompanied by any decisive powers. Another law was passed in 1984 (Law 1416/ $84)$, dealing with the promotion of municipal entrepreneurship and the creation of a legal framework for voluntary municipal mergers. Once again, its impact proved to be marginal. Only 31 voluntary mergers took place, despite the generous incentives offered, whereas municipalities hardly grasped the opportunity to develop entrepreneurial skills. ${ }^{19}$

The most important innovation of the decade was the introduction of a regional level of government with Law 1622/86. The Greek territory was subdivided into 13 regions. Each one of them was presided by a secretary general

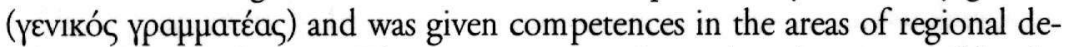
velopment and planning. The secretary general was directly appointed by the central government. There were also provisions in the law for the creation of elected prefectural councils (in reality, $75 \%$ of their members were to be directly elected), but the presidential decrees necessary for the activation of this part of the law were never issued.

It is clear that the rhetoric adopted by PASOK was never matched in practice. The government introduced a number of innovations, in order to increase citizens' participation in subnational government. Nevertheless, increased participation did not necessarily mean a stronger voice for the people in regional and local affairs. Additionally, the new bodies that were created hardly enjoyed any serious competences and remained marginalised.

There were many elements that contributed towards the relative inertia of the 1980s. A very important factor against the reforms was the central ministries' bureaucracies that dreaded the loss of power to the benefit of local political and administrative elites. When repeatedly asked to provide information on which competences they could surrender to the prefectures, they either refused to give the relevant information or were in favour of surrendering only the least important tasks. ${ }^{20}$ At the same time, many politicians at the

19. Ibid, p. 89.

20. P. Kaler-Christofilopoulou, Decentralisation in Post-Dictatorial Greece, Unpublished PhD Thesis, London School of Economics and Political Science, London 1989, pp. 301, 313. 
central level fiercely opposed the creation of elected government at the prefectural level, since they were afraid they would lose their own privileges and their clientelistic networks within the prefectures, which also served as constituencies. Thus, both old-style politicians and central ministries' bureaucrats saw it as being in their interest to block the introduction of prefectural selfgovernment. ${ }^{21}$

Even politicians at the local level tended to be against municipal mergers and the reorganisation of Greek local government. There were many heads of

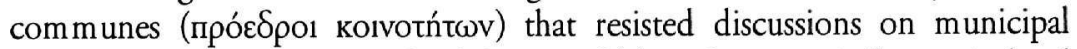
mergers, because they were afraid they would lose their own influence in local affairs. All in all, a number of factors pushed towards path dependence and the retention of the status quo.

Those factors were to some extent counteracted by the influence of other forces pushing towards the territorial restructuring of the country. Contrary to what one might believe, the role of the European Union (then $\mathrm{EEC} / \mathrm{EC}$ ) in the 1980s was marginal. Of all reforms undertaken, only the creation of the regions was directly influenced by the EEC/EC.

All existing literature on the subject agrees that the creation of the regions should be attributed mainly to the EU. ${ }^{22}$ One should bear in mind that the 1986 law followed the implementation of the Integrated Mediterranean Programmes (IMP). The country experienced considerable pressure in its effort to absorb the money, since its centralised regime and inefficient public sector did not allow for an efficient use of funds. This resulted in the need for the creation of regional authorities that would be able to manage future European funding. ${ }^{23}$

Additionally, the country had to adapt to the newly established EC requirements that asked for the drafting and implementation of the programmes "at

21. F. Papoudakis, The Impact of Structural Funds Regulations on Regional Policy Process in Greece, Unpublished PhD Thesis, The University of Edinburgh, Edinburgh 2001, p.94.

22. F. Papageorgiou - S. Verney, "Regional Planning and the Integrated Mediterranean Programmes in Greece", op.cit.; S. Verney, "Central State-Local Government Relations", op.cit.; K. Featherstone - G.N. Yannopoulos, "The European Community and Greece: Integration and the Challenge to Centralism", op.cit.; P.C. Ioakimidis, "EU Cohesion Policy in Greece:

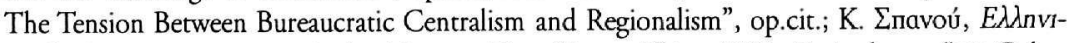

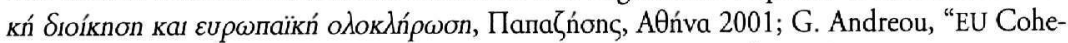
sion Policy in Greece: Patterns of Governance and Europeanization", op.cit.

23. P.C. Ioakimidis, "EU Cohesion Policy in Greece: The Tension Between Bureaucratic Centralism and Regionalism", op.cit. 
the relevant geographical levels" and were asking for the application of the principles of subsidiarity and partnership. ${ }^{24}$ This explains why the newly created regions had competences only in the area of regional development and planning.

All other reforms of the decade should be attributed mainly to domestic factors. Of course, the reforms that were achieved reflected the governing party's ideology, while there was also pressure stemming from the PASOK manifestos and initial promises. ${ }^{25}$ At least during the first four years in office, PASOK's reforms were influenced by a strong democratisation discourse and a perception that there should be more participation of citizens in local affairs. However, as the decade progressed, the initial revolutionary spirit of the Socialist government waned alongside its eagerness to reform. The realities of governing had moderated PASOK's enthusiasm towards a radical version of decentralisation. Instead, it became more pragmatic in the reforms it envisaged. Of course, decentralisation remained quite high on PASOK's agenda, but its new version of it never approached the original image pictured in the party manifestos of the 1970 s.

\section{THE 1990's}

In the beginning of the 1990s, even the modest momentum that had been achieved in the 1980s was lost for a period of time. PASOK, which had, at least to some extent, endorsed decentralisation as a major political goal, was no longer in power from 1989. Nea Dimokratia, which was now in government, was not particularly keen on decentralisation reforms, because of its own ideological reservations. At the same time, the deterioration of public finances and the radical political changes taking place in Europe were far more important issues to deal with.

However, after PASOK took office again in 1993, the decentralisation process started afresh. It was then that the prefectural self-government was created. After decades of debating it, an elected second tier of local govern-

\footnotetext{
24. Council Regulation (EEC) 2088/1985; see also, S. Verney, "Central State-Local Government Relations", op.cit.

25. P.C. Ioakimidis, "EU Cohesion Policy in Greece: The Tension Between Bureaucratic

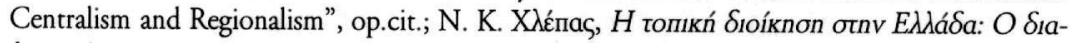

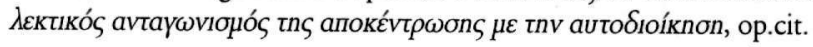


ment was to be implemented (Law 2218/94). The law was hastily drafted and it took a number of further, correcting and clarifying, laws before it was finally put in place. ${ }^{26}$

Most of the changes that did happen in the 1990s took place in the period between 1997 and 1999, after the so-called modernising faction within PASOK, also known as the Modernisers (EкouүXрoviotés), ascended to power. Under the leadership of the then Prime Minister Kostas Simitis and especially the Minister of the Interior, Alekos Papadopoulos, important legislation was initiated. The role of the regions as a subnational level of deconcentrated government was clarified and their administrative structure strengthened (Law 2503/97). The acute issue of the extreme fragmentation of local government authorities was tackled with compulsory municipal mergers (Law 2539/97). ${ }^{27}$ Hence, their numbers were decreased from just below 6,000 to 1,033 and their competences enhanced. However, the major urban centres of Athens and Thessaloniki were exempted from the reform, and although another piece of legislation was supposed to be initiated at a later date regarding the geographical areas of Attica and Thessaloniki, this never materialised. Additional competences were passed to regional, prefectural and municipal authorities (Law 2647/98), and the finances of the prefectural authorities were to some extent rationalised, more than four years after the introduction of the elected prefectural authorities.

Hence, by the end of the 1990s the landscape of subnational government in Greece had changed significantly. There were now two levels of elected local government (at the municipalities and the prefectures level), while the regional authorities were moderately strengthened. Additionally, the number of local authorities was reduced radically and their competences increased.

Nevertheless, there were many important issues that were not tackled, and the subnational architecture of the country remained incomplete. The role of the prefectures seemed to be rather ornamental in the inter-governmental relations of the country, especially after the strengthening of both regions and municipalities. ${ }^{28}$ More importantly, the subnational government finances remained in a dire state. As a matter of fact, the more competences were trans-

26. V. Leontitsis, Decentralisation Reforms in Greece (1981-2008): Exploring Inertia and Change, op.cit.

27. The so-called "Kapodistrias" reform.

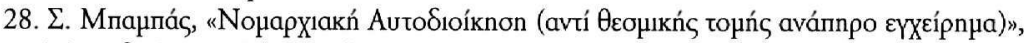
Tonı́ń Autodıoíknon, Vol 1 (114), 1998, p. 16. 
ferred without adequate funds to exercise them, the worse the subnational government finances became.

The most important factors propelling the aforementioned reforms were, once again, mainly domestic in nature. During the 1990s, issues of democratisation seized to be as important as they were in the 1980s. The country had experienced stability and democracy for a good number of years, and thus the democratic craving of the 1970s and the early 1980 s was to some extent satisfied. Progressively, it was managerial and efficiency concerns that started gaining prominence. Elements of New Public Management (NPM) were progressively incorporated into the Greek public administration, albeit with modest outcomes. ${ }^{29}$ Hence, a number of innovations, such as the strengthening of the regional authorities and the creation of a financial scheme for the prefectures, can be more clearly understood through the prism of the effort put into rationalising Greek public administration.

The Modernisers' rise was the catalyst for the radical reforms of the second half of the 1990s. The logic behind the reforms they attempted was fundamentally based on a modernisation discourse. This discourse affirmed that for modernisation to be achieved Greek public administration in general and subnational government in particular had to function in better ways. The Modernisers stressed that the role of the central state should be steering and supervisory in nature, while subnational government should be able to exercise most executive powers.

Of course, beyond this rational perception of public administration there were plenty of forces opposing any change to the status quo, aiming at retaining long-acquired benefits and powers. The prefectural self-government was brutally fought against by many MPs. ${ }^{30}$ Additionally, the municipal mergers were fought fiercely not only by local politicians, but also by local societies. ${ }^{31}$

29. NPM is a term difficult to define. One could argue that it entails the introduction of private sector management techniques into the public sector. Increased attention is paid to efficiency, productivity, target setting and revision, cost reduction, professionalisation, decentralisation, privatisation and contracting out.

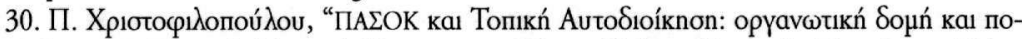

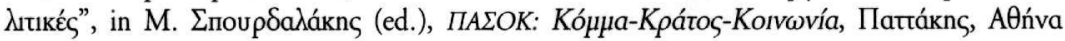
1998, p. 207.

31. For the protests that took place during that period, see K. Пвтропоú $\lambda$ ou (ed), «Kuvou-

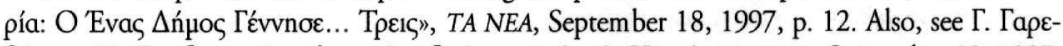

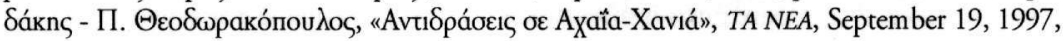
p. 9. 
The man that proved to be a policy entrepreneur, ${ }^{32}$ initiating and supporting the radical reforms of 1996-1998, was the then Minister of the Interior, Alekos Papadopoulos. He pushed the reforms up the government agenda, despite opposition. When there were many voices from within and outside his governing party calling for the withdrawal of the "Kapodistrias" law, he stood his ground and managed to achieve a favourable outcome. Alekos Papadopoulos provided the necessary leadership. He insisted on change and was oblivious to the political costs which his decisions would inevitably bring about.

The role of EU became more important during the 1990s. However, the extent of its importance has been fiercely debated. Ioakimidis, for example, has stated that most decentralisation reforms "were introduced as a response to the requirements of EU membership", ${ }^{33}$ refuting his earlier argument that "the impact of the EU on institutional arrangements has been rather marginal" ${ }^{34}$ Other scholars abide by the latter statement. ${ }^{35}$

As a matter of fact, the role of the $\mathrm{EU}$ remained indirect, which is why it is so difficult to acquire a sense of its relative importance. Although there were no direct pressures regarding the institutional structure of the country, the necessities deriving from the EU regional policy and the incoming Economic and Monetary Union (EMU) had both positive and negative effects on the relative position of subnational authorities.

For example, because of the poor performance of Greece during the first programming period, and after pressure from the Commission, an array of agencies and semi-public bodies were established to assist in the handling of regional funds. ${ }^{36}$ In the early 1990s external project management advisors were hired from the private sector, whereas during the 2nd Community

32. According to Kingdon, policy entrepreneurs are individuals that are willing "to invest their resources -time, energy, reputation, and sometimes money- in the hope of future return". See J.W. Kingdon, Agendas, Alternatives, and Public Policies, op.cit., p. 122.

33. P.C. Ioakimidis, "The Europeanization of Greece: An Overall Assessment", op.cit., pp. 85-86.

34. P.C. Ioakimidis, "EU Cohesion Policy in Greece: The Tension Between Bureaucratic Centralism and Regionalism", op.cit., p. 358.

35. G. Andreou, "EU Cohesion Policy in Greece: Patterns of Governance and Europeanization", op.cit., p. 253.

36. F. Papoudakis, The Impact of Structural Funds Regulations on Regional Policy Process in Greece, op.cit.; G. Andreou, "EU Cohesion Policy in Greece: Patterns of Governance and Europeanization", op.cit., p. 250. 
Support Framework, the Management Organisation Unit (MOU) was set up. The role of the Commission, and the Regional Policy DG in particular, was fundamental in influencing the establishment of those auxiliary institutions. The weak administrative capacity of the regions had compromised their ability to handle EU regional policy funds successfully and, since both the Greek government and the Commission became increasingly more preoccupied with issues of efficiency and fund absorption, the regions were soon partly supplanted in the regional policy process by those new institutions.

The pressure to create the necessary structures to absorb the EU money had led to the establishment of the regions in the late 1980s and thus worked in favour of the regional tier of government. Paradoxically, the same forces, in the 1990s, threatened to reduce the influence of the regional and other subnational authorities in regional policy. Hence, although the regions were strengthened administratively in absolute terms, their role was weakened vis-à-vis the central government and other newly institutionalised bodies dealing with regional policy (see above).

EU influence on the finances of subnational government was far greater than any institutional effects. EU funds provided the Greek subnational authorities with a considerable amount of money, which they were in real need for. The municipalities in particular were able to put forward a number of projects that were financially supported by the EU funds. However, the increased flow of funds from the EU did not signify increase subnational government influence in shaping regional policy. Instead, they remained secondary players that just made use of funds available to them. ${ }^{37}$

At the same time, the Greek central government continued depriving subnational authorities of funds they needed urgently. The situation became considerably worse by the end of the 1990s and the beginning of the 2000s, since competences were transferred away from the central government, but funding of subnational authorities did not increase at the same pace. ${ }^{38}$ Part of the reluctance shown by the central government to fund subnational authorities was due to its efforts to reduce the country's deficit and fulfill the Maastricht economic criteria to participate in the EMU. Hence, Europeanization proved to be a complicated factor. Aspects of it strengthened subnational authorities, while others weakened them.

37. I am indebted to George Andreou for this point.

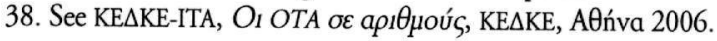


The way domestic and international factors have combined at times can be clearly seen when explaining the timing of the major reforms of the 1990s. Fear that Greece could be left out of the EMU was a powerful weapon in the hands of the modernising forces within the country in general and within PASOK in particular. When the modernising faction of PASOK came to power, it had a clear plan to advance a wider reform ist agenda by tying it to the prospect of Greece's inclusion in the EMU. One of their goals was to reform subnational authorities, transferring competences to them and rationalizing their functions. Thus, innovations at the EU level and the prospect of further integration empowered certain political actors within the country and indirectly influenced decentralisation reforms.

\section{THE 2000's}

After the radical reforms of the years 1996-1998, the pace of territorial restructuring subsided. The most important innovation at the beginning of the 2000 s was the constitutional amendment of 2001. The Constitution of 1975 was not really progressive in terms of the structure and the competences of subnational authorities in Greece, while it also left many issues unresolved. ${ }^{39}$ In particular, it devoted only two articles to subnational authorities. Article 101 dealt with issues related to the deconcentrated authorities, while Article 102 dealt with local self-government.

The 2001 constitutional amendment altered both articles 101 and 102, and this amendment is still valid today. Among other things, control over subnational authorities is now confined to legality issues. The central government cannot question the scope of subnational authorities' decisions. The number of elected subnational authorities is for the first time officially state, since there are provisions for two levels of elected subnational government. Finally, it is explicitly stated that the central State cannot transfer competences to subnational authorities without transferring the necessary funds for their exercise.

It is true that the constitutional amendment did not alter much in practice, since it mostly adopted elements that had already been in place. Nevertheless, it was of particular significance, because it crystallised the changes that had

39. V. Leontitsis, Decentralisation Reforms in Greece (1981-2008): Exploring Inertia and Change, op.cit. 
taken place in Greece since the beginning of the 1980s. More importantly, there was broad consensus among the main political parties regarding the amended constitutional provisions and the whole process was described as a "consolidation of past reforms by consensus". 40

The next few years marked a period of relative stability for subnational authorities. However, below the relatively stable surface, tensions continued and discussions were held about the future of subnational government in the country. Municipal and prefectural conferences were held agreeing that further mergers had to be implemented, in a so-called "Kapodistrias II" reform. A window of opportunity opened, but the anticipated reforms did not materialise, mainly due to a lack of political entrepreneurship (see below).

Although the territorial design of subnational government in Greece seemed to have achieved an unstable equilibrium, it changed once again radically in 2010, with the most far-reaching subnational government reform to date. Law 3852/2010, or the "Kallikratis" reform as it is popularly known, reduced the number of municipalities further from 1,033 to 325 , abolished prefectures altogether, transformed the regions into the second level of subnational self-government and created seven decentralised administrations (апо-

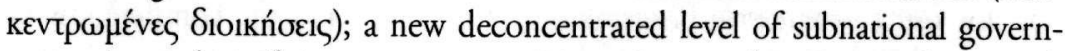
ment. A number of new competences were given to the municipalities, such as in social policy, agriculture and planning. Even more competences were reserved for the island municipalities. The latter, with the exception of the really small islands or the really big islands of Crete and Euboea, were to form one municipality each following the so-called one island - one municipality principle.

But what was behind the changes of the 2000s? And why was there relative stability followed by the radical changes of the "Kallikratis" reform? The perceptions of the two major parties, Nea Dimokratia and PASOK, toward subnational government had progressively converged. The former was no longer against decentralising the polity anymore and its positions had become more or less identical to those of PASOK. Of course, there were voices in both parties against giving away too much power, but at least in terms of polity design

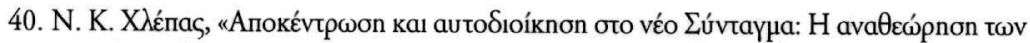

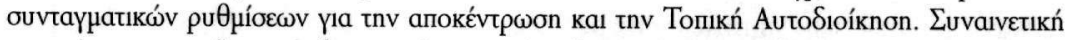

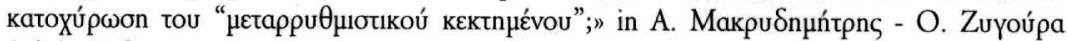

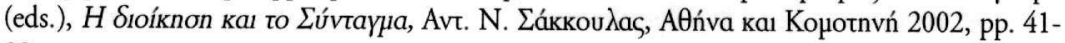
89. 
their views converged. Hence, it should not come as a surprise that there was a high degree of agreement in the constitutional amendment, which was a rare example of consensual politics in a country where confrontational politics constitutes the norm.

Years of operating within the broader European framework and the influence of a global neo-liberal ideology had played their own part in achieving and maintaining a minimum consensus between the major stakeholders. New Public Management (NPM) had gradually become the overarching discourse underpinning the territorial restructuring discussions. Its most important influence had to do with the nature of the reforms. Most changes were now related to managerial or financial concerns. It is interesting to observe how the system moved towards reforms that targeted the creation of more productive and functional subnational authorities. Most efforts pointed toward improving the role of subnational government as a provider of public goods.

However, one should not overestimate the ability of NPM to change radically Greek public administration. NPM became the overarching principle that the proponents of reforms tended to invoke, but it failed to penetrate deep into Greek public administration. Hence, a major paradox occurred. NPM dictated most of the attempted reforms of the decade, but its failure to be widely defused and accepted within Greek public administration challenged the success of these reforms in practice.

A major internal obstacle to reforms remained the negative stance of a great portion of the central political and bureaucratic elites. Modernisers from all segments of society were often the ones supporting the decentralisation of the polity, whereas more traditional forces wanted to preserve the centralised status quo, thus opposing NPM. Yet, ideology alone cannot explain the resistance posed by the system. A lot of central ministry officials and politicians opposed decentralisation because they were eager to sustain the power they had accumulated. They tried to obstruct any transfer of power away from them, and even when favourable conditions for decentralisation reforms made it impossible to resist, they attempted to retain control over financial resources; an important source of power.

However, the most important factor against exploiting the window of opportunity that had opened was the lack of a policy entrepreneur that would exploit the relative convergence in the views of the principal actors, in order to initiate radical reforms. Three successive Ministers of the Interior (Vasso Papandreou (1999-2001) and Kostas Skandalidis (2001-2004) for PASOK, as 
well as Prokopis Pavlopoulos (2004-2009) for Nea Dimokratia) agreed that far-reaching reforms had to be instigated, but failed to promote them, possibly fearing the accompanying political cost.

Domestic factors, both positive and negative, remained crucial. However, international factors, such as Europeanization, globalisation and policy transfer continued growing in importance. During this period, Greece became increasingly exposed to globalisation. Changes in transportation and technology meant that distances were shortened and the meaning of 'local' was reassessed. The economic and social transformations that were taking place arguably required bigger and more efficient subnational units that would be able to compete in the global environment.

Experience with the EU had shown that bigger subnational units were needed to handle the EU funds more efficiently. Moreover, years of association with the EU institutions had distilled a certain amount of sympathy among reformists towards the creation of a stronger regional tier of government. The EU policies privileged fewer and stronger subnational authorities. This could be achieved with a second round of municipal mergers and a reduction in the number of regions. In such an institutional landscape there was no place for the prefectures.

As the country increasingly engaged with its global and European surroundings, communication with the bureaucracies of other countries also intensified. Increasing socialisation forced Greece to look at the way other countries administered their own territories. In many cases, this remained a secondary factor that could indeed influence reforms, albeit in an indirect and thus less visible way. It is interesting to notice, for example, that the two waves of compulsory municipal mergers in Greece followed, with some delay, similar reform efforts that had taken place in other European countries in the past. Reforms in other countries could set examples for domestic innovations.

The convergence in the beliefs of a number of actors opened a window of opportunity since the early 2000 s, but without a policy entrepreneur to champion the idea of reforms it failed to deliver any concrete outcomes. It was only when the Minister of the Interior for the newly elected PASOK government, Giannis Ragoussis, attempted to promote substantial changes in 2009-2010, that the country's subnational architecture was finally redrawn.

The fact that Ragoussis had been a mayor of Paros before, which is a small Greek island, influenced some of the policy decisions in the "Kallikratis" law, such as the extended provisions related to island municipalities. "Kallikratis" 
also reflected the need for larger subnational authorities, as discussed above. The law was met with hostility by local communities, which saw their voice (and privileges) being lost within subnational authorities that were possibly too large to be close to the citizen. However, Ragoussis persisted and it was his persistence that allowed for a reform which is going to have long-lasting effects on Greece's territorial structure.

This last reform took place within an environment of intensified international and domestic financial crisis, which has brought about deep changes in the Greek political, social and economic lives. The crisis has started altering fundamentally the way subnational government functions, but its direct and indirect results are to be seen in the years to come.

\section{DISCUSSION}

It follows from this analysis that the process of the territorial restructuring of Greece has been unfolding in various paces for decades, while major decisions are still pending. In that sense, it is a reform process that is far from complete. However, a number of obvious themes have been prevalent that deserve some discussion:

- Intergovernmental relations. A major question is whether or not subnational authorities have been strengthened after all those reforms that have taken place from 1980 onwards. Arguably, there has been a degree of decentralisation of the polity in the last thirty years, and subnational authorities have been strengthened. However, the strengthening of subnational authorities that has been achieved is not as pronounced as one would expect. In Greece, the legal reality does not necessarily correspond to the political realities, since laws are not always fully implemented in practice. In the case of the Greek subnational authorities the most weakening factor is the fact that they are traditionally kept hostage in economic terms. It is undeniable that their competences have increased. However, their relative financial position is still in a perilous state. The central government has withheld money that is necessary for the exercise of competences. As a matter of fact, this practice has become especially pronounced from the late 1990s onwards. Hence, in relative terms the financial position of subnational government has deteriorated. It is expected that the current financial crisis is going to worsen its net financial position even further.

- Domestic vs. International factors. Europeanisation has only been a secondary 
factor in the process of the territorial restructuring of the country. In all three decades explored, it was mainly domestic factors that pushed for the reforms analysed in this article. In the 1980s, it was the pro-decentralisation ideology of PASOK, no matter how superficial, that was the engine behind the meager reforms, alongside a general quest for the democratisation of the polity. It was only in the creation of the regions, in 1986, that Europeanization played an important role. In the 1990s, the major discourse gradually shifted from the need to democratise the polity towards better efficiency in subnational government. After the PASOK Modernisers' advent to power in 1996 the quest for achieving more efficiency and for modernising the country became a discursive focal point. The EU regional policy did not always work towards the empowerment of subnational authorities. Sometimes, the requirement to absorb the EU regional policy funds in a fast and efficient way worked against the empowerment of the weak Greek subnational authorities. Finally, in the 2000 s the convergence of the official political views held by the two major parties, which partly needs to be understood against the background of the New Public Management discourse, played an important role. At the same time, globalisation, Europeanization and policy transfer became more pronounced.

Throughout the years, a multitude of factors worked against this slow decentralisation process. Politicians at the central and local levels, the ministries' bureaucratic elites, as well as the general public fear towards new subnational authorities' schemes played their own role in slowing down reforms, or in some cases even reversing them. Those factors were predominantly domestic in nature and were strong enough at times to successfully retain the status quo. Nevertheless, as stated in the introduction, it would be naïve to attempt a complete and clear separation between domestic and international factors. Domestic factors played a decisive role towards the final outcome, but in many cases the international factors were potent enough to influence the domestic arena by empowering certain actors and weakening others. The case of the PASOK modernising faction, for example, and the widespread reforms which Simitis' government attempted to enact in the second half of the 1990s, should partly be soon through the prism of the incoming EMU and the Greeks' desire to become part of it.

- Incremental vs. Radical change. A major question, already touched upon in the theory section, is to what extent the punctuated equilibrium thesis holds in the case of subnational government reforms in Greece, or whether there has instead been slow, progressive change towards the decentralisation of the 
country. This question is difficult to answer, since the answer depends on the way one perceives change. If change means the official alteration of rules, then of course, then of course there are important laws, such as the 1986 law on the introduction of the regions, the 1994 one on the introduction of the prefectures, the 1997 "Kapodistrias" law and the 2010 "Kallikratis" reform that could pose as the candidates for institutional breaks. However, apart from those radical laws, there has been a multitude of other legal documents, of lesser importance, which have also shaped the current institutional design of the country. But even beyond that, there have been many decisions (such as decisions by prefects, mayors etc.) or omissions (such as not issuing presidential decrees as dictated by a law, or withholding finances that had been earmarked for subnational government) that have played their own important role in the story of decentralisation in Greece.

Hence, one should be careful before endorsing the punctuated equilibrium thesis too readily. There has never been a period of complete pause of reforms. Instead, the number of reforms and the magnitude of change have fluctuated. All in all, what one observes in this process is that greater and smaller changes, factors that have pushed for and factors that have obtruded reforms have been well entangled in a complicated pattern of relations that has altered in shape over time. This mesh has never seized to exist and produce outcomes.

- The role of actors. Alekos Papadopoulos' role in promoting the reforms during the years 1996-1998 is undeniable. His ability to accomplish a number of reforms shows that actors are capable of changing the course of reforms when the timing is correct and when they are equipped with certain qualities, such as leadership abilities, persistence and perseverance. However, it would be equally wrong to perceive actors as omnipotent, free from the limitations that the overarching structure imposes on them. Alekos Papadopoulos managed to pass the "Kapodistrias" reform through the Greek Parliament, despite the fierce opposition he faced. However, the reform of the first degree of local government remained incomplete. He had to accept a higher number of municipalities being created than initially envisaged, while he never managed to bring a second law in the Parliament dealing with the municipalities of the densely urbanised areas of Attica and Thessaloniki. Similarly, although Yannis Ragoussis managed to pass the most far-reaching reform to date in 2010, the "Kallikratis" reform has been compromised by the acute financial crisis the country has been experiencing in the last few years.

This brings to the forefront the relationship between actors and structure, 
which is necessarily dialectical in nature. Structure is powerful and shapes, to a great extent, the actors' perceptions of, and abilities to, change the system. However, from time to time, powerful actors do manage to seize windows of opportunity and change an existing structure. Other times, the window of opportunity is open, but because of the actors' inaction and lack of leadership it is left to close. This is what happened in most of the 2000s when conditions were ripe for radical changes, but no Minister of the Interior took the responsibility to sponsor them. However, apart from those radical changes enacted by potent actors' decisions, more research is needed to shed light on the multitude of actions taken by rather insignificant actors, who manage to gradually shape the landscape of public administration.

\section{CONCLUSIONS}

This article has shown that the widespread perception of Greece as a highly centralised polity with no ability or incentive to reform is misleading. There is no doubt that the country remains highly centralised. However, many farreaching subnational government reforms have taken place in the last thirty years. The number of municipalities has been decreased radically, while there has been experimentation regarding the number and nature of subnational authorities.

This change has not come about abruptly. Instead, it has constituted a dynamic process that has had its own moments of acceleration and setbacks. A multitude of factors have influenced the process, which has been non-linear and dynamic in nature. The territorial restructuring drama is hardly over. New episodes of it are going to unfold in the future, bringing about further alterations.

However, one should stress that there are also powerful factors that have been capable to block an even more radical reorganisation of the Greek polity. The distribution of power among the different levels of government still favours the central state. The tectonic shift that is needed for Greece to become decentralised has not occurred yet. The central state still controls important financial, administrative and political tools to dictate the rules of the game in intergovernmental relations. Despite the changes that have taken place and the reforms that might follow in the future, the essentially centralised design of the Greek polity is still largely in place. 